\title{
Risk in an individualistic society - the basis of public attitudes towards the nuclear industry in contemporary Britain
}

\author{
R. Wylie and K. Rackham \\ Westlakes Research Institute, International Research and Graduate Centre, \\ Westlakes Science and Technology Park, Moor Row, CA24 3JY, Cumbria, U.K.
}

\begin{abstract}
In contemporary society, developments in the social, political and technological environments are leading value orientations to move towards "individualisation". These changes have significant implications for public acceptance of risks, in particular for the nuclear industry. The key paradox of risk perception among Individualists is that they are more risk aware but less risk averse. Individualists heighten the importance of self in their evaluation process as they undertake "balancing behaviour", a cognitive cost-benefit analysis based upon the perceived benefits and disbenefits of the nuclear industry. Our research of public attitudes in the community around the Sellafield nuclear reprocessing plant suggests that even in close proximity to a perceived high-risk facility, individualists perform a more thorough analysis of referents in the formation of an attitude. There are significant implications for risk communicators; they need to characterise the value orientations of their intended audiences effectively, both to establish appropriate channels of communication, and to adapt their message to address the key concerns of their audiences. However, in this age of individualisation, the key question may just be "What's in it for me?"
\end{abstract}

\section{INTRODUCTION}

We live in an age of anxiety. Risk has become a major concern for individuals, communities, governments and administrations (Beck [1]). As an American risk analyst argued, "Society [is] becoming extremely risk-sensitive... We're in a kind of frantic search for security", a "fail-safe society" (Piller [2]). Risk and insecurity are part of the contemporary discourse; the sensationalist print and broadcast media are full of it, El Nino, beef on the bone, pasteurised milk, genetically modified food or meteor strike.

With increased public concern regarding environmental issues, ever greater demands are placed on decision makers to understand the public perception of risk when setting environmental standards and developing policies. The nuclear industry appears to be especially vulnerable to risk perceptions. In 1997, for example $81 \%$ of people in the UK were "concerned" or "very concerned" about the risks posed by nuclear power plants, $91 \%$ about nuclear waste disposal, and $87 \%$ about the transport of nuclear material. Compare this with $50 \%$ about the risks associated with oil refineries. (All data: RAS for Newcastle University, 1997).

\section{PUBLIC ATTITUDES TOWARDS THE NUCLEAR INDUSTRY}

\subsection{An industry out of favour in the UK}

As Slovic [3] explains, nuclear risks "... occupy extreme positions in psychometric factor spaces, reflecting people's views that these risks are unknown, dread, uncontrollable, inequitable, catastrophic and likely to affect future generations". In the UK, public attitudes towards the nuclear industry may be characterised as negatively polarised. In 1997 , only $19 \%$ of the general public were favourable towards nuclear power. UK nuclear industry may also be characterised as being of low salience and proximity. 
Few realise that only over $20 \%$ of UK electricity is generated by nuclear power and that the industry is geographically dispersed across the UK, located well away from most centres of population.

\subsection{The impact of locality}

Given the 'dread' connotations of nuclear power, there is an apparent paradox that in the vicinity of nuclear facilities, support for the nuclear industry is much higher than in areas where the majority live some distance from them. In West Cumbria, site of the Sellafield nuclear reprocessing and power complex, $70 \%$ of the population were favourable towards the nuclear industry, even though almost $60 \%$ of the same group believed that "it is risky and there is a constant danger of an accident". (Source: CNR for Newcastle University, 1997).

Close proximity often leads to a more thorough evaluation in the development of an attitude: perceived risks are balanced against perceived benefits; in the case of West Cumbria, the belief that the industry underpins the economic and social fabric of the region. The nuclear industry provides almost half of the jobs available in the locality, and many other jobs depend on the plant through linkage in terms of goods and services provided. The nucleat industry has become part of the local area and residents are proud of it.

Nationally, however the nuclear industry is perceived not to be proximate to individuals and there is little to balance against the belief that it is risky, costly, secretive and environmentally damaging. There are negative beliefs attached to the nuclear industry, such as weapons use and nuclear proliferation, with dread connotations such as risk of nuclear war; recently these beliefs have been amplified by the belief that the industry itself may actually be incompetent.

\section{TOWARDS AN INDIVIDUALIST SOCIETY}

There are trends in contemporary Britain which appear to be modifying the value systems of the mass public that may be affecting the role of beliefs about risk in the development of attitudes towards the nuclear industry at the national level (Wylie and Hague [4]). The result of these trends appears to be the emergence of a new structure of feeling, a value orientation which we term "individualist". This structure of feeling has significant implications, we believe, for risk communications about environmentally sensitive industries like the nuclear industry.

\subsection{Key themes to individualism}

There are four key themes contributing to the development of an individualist value orientation. Firstly, concerning quality of life, increasing concerns about economic growth, property and security, freedom of expression and the natural environment. Secondly, the disembedding of individuals from traditional social, political and economic relations. Thirdly, reflexivity (Giddens [5]) as public, science and society come to reflect on the dangers posed by industry, science and technology and increasingly question of roles and efficacy of modern society, its institutions and traditions (Beck [6]). And fourthly, risk (Beck, [7]). All of these themes contribute to the development of an increasingly assertive individualism among the UK general public.

These themes underlie one of the key value orjentations in contemporary society - individualism (Wylie and Hague [4]). Often assertive and aggressive, individualism is shaped by economic, political and cultural trends in society, it manifests itself in two main ways, positively and negatively. Firstly, positively through an insistence on personal autonomy - of opinion, choice, and action - in all areas of life salient to the individual, and by a strong desire for personal freedom of expression, not only in the sphere of politics, conventionally understood, but throughout the wider sphere of an individual's social and cultural activities and relationships. Secondly in a negative way, by a secular decline in the level of public affiliation with social, political and cultural groups. 


\subsection{Identifying individualist value orientations}

From a national opinion survey, two questions were particularly relevant to identifying this tendency in respondents' value orientation. Firstly, responses to the statement "Personal freedom of choice in all aspects of life is very important to me"; emphatic agreement with this statement is taken as one indicator of an individualistic outlook. Secondly, reflecting a decline in group affiliation, whether an individual was close to any political party; a negative response to this was taken as a second indicator of an individualist outlook.

Table 1: Identification of value orientations, by group

\begin{tabular}{|c|c|c|}
\hline & Frequency & Percent \\
\hline Group 1 gave neither response (Traditionalist) & $2 \overline{87}$ & 9 \\
\hline Group 2 gavę one response (Mixed) & 1392 & 45 \\
\hline Group 3 gave both responses (Individualist) & 1426 & 46 \\
\hline Total & 3105 & $100 \%$ \\
\hline
\end{tabular}

Source: RAS national poll for Newcastle University, February 1997 (figures have been rounded)

The table above reveals our findings. It shows that, by our method, almost half of the sample of 3105 $(46 \%)$ could be termed individualist. The data from the national opinion survey showed that individualist orientations were rather more prevalent among the young and middle aged than among older respondents. In terms of social class, the value groups are not demographically distinctive - traditionalist, mixed and individualist orientations are dispersed across all major social categories.

\section{EXTERNALISATION OF RISK AWARENESS}

\subsection{Perceived risk from the belief of a threat}

After Wildavsky [8], risk may be defined as the perceived probability of the occurrence of a negatively valued event. This is not objective risk; rather it is perceived risk - a perception or belief that a salient threat exists, which determines individual action. In this context, risk is not necessarily an objective reality, though scientific communications may discover and present risks, such as the scare of CID, the human form of BSE. Adams [9] explains that the essence of risk is that the future is unknowable: individual's evaluations of risk are based on experience of the past, and their projection into the future, in a particular 'present' or setting. West Cumbrians, for example, can base their personal evaluation of the nuclear industry upon a lot more information on past experience than the national population.

Some risks are perceptible, such as the dangers associated with crossing a road. Other risks may not be directly perceived by individuals but are equally powerful in determining individual's actions, perceived through science (and promulgated by the sensationalist media); they include risks upon which science agrees, such as estimates of radioactive discharges. The third type of risks includes those, which scientists do not know or cannot agree on (Gaskell [10]), such as the trajectory of global warming.

Though perceived risk may be intangible and abstract, its effects as enacted behaviour or expressed opinion can have very significant commercial, personal or political consequences, as it was the case for the Brent Spar oil platform (Wylie and Hague [4]). 


\subsection{Importance of external influence on individual risk evaluation}

In reality, lay risk perceptions may involve a package of beliefs from a range of sources, some of them external to the individual including the media, peers or scientists. Indeed, the lay person's conceptualisation of risk may be very broadly based, reflecting all manner of concerns (Slovic [3]). This 'externalisation' of risk awareness suggests that particular social or cultural or economic locations may have a unique and distinctive bearing upon the role of risk in individuals' evaluations. Values, which are shaped by culture, and the social, political and economic environments within which people live, are key structures in the individual's cognitive system. They lie in the centre of the risk evaluation process (Wylie and Hague [4]).

Moreover, lay evaluations of risk may reflect all manner of concerns, including issues not logically or objectively connected with the matter at hand from an 'expert' perspective. Many factors may be taken into account in this process. Wildavsky [8] proposes an "axiom of connectedness" in which positive and negative beliefs about an object or issue under consideration are intertwined as the perceived utility of a particular attitude object is offset against the perceived hazard. Risk may, therefore, be an important part of the personal decision making process, used by individuals to optimise future courses of action by selecting a level of risk appropriate to, or consistent with, the gains they perceive as accruing from them. Like in West Cumbria, where beliefs about nuclear risks are offset against beliefs about economic and social benefits - even though people still believe it is very risky.

\section{IMPACT OF INDIVIDUALISATION UPON RISK PERCEPTION}

In the following tables, we compare levels of concern at risks posed by three aspects of the nuclear power industry; nuclear plants, waste disposal and transportation.

Table 2: Concern posed by nuclear power plants

\begin{tabular}{|l|c|c|c|}
\hline & $\begin{array}{c}\text { Traditionalists } \\
\%\end{array}$ & $\begin{array}{c}\text { Mixed type } \\
\%\end{array}$ & $\begin{array}{c}\text { Individualists } \\
\%\end{array}$ \\
\hline Very concemed & 45 & 49 & $\mathbf{6 0}$ \\
\hline A little concemed & 32 & 32 & 27 \\
\hline Neither concemed nor unconcerned & 4 & 6 & 3 \\
\hline Mainly unconcemed & 12 & 9 & 7 \\
\hline Totally unconcerned & 4 & 3 & 2 \\
\hline Don't know & 3 & 2 & 1 \\
\hline & $100 \%$ & $100 \%$ & $100 \%$ \\
\hline
\end{tabular}

Table 3: Concern posed by nuciear waste disposal

\begin{tabular}{|l|c|c|c|}
\hline & $\begin{array}{c}\text { Traditionalists } \\
\%\end{array}$ & $\begin{array}{c}\text { Mixed type } \\
\%\end{array}$ & $\begin{array}{c}\text { Individualists } \\
\%\end{array}$ \\
\hline Very concerned & 65 & 67 & 81 \\
\hline A little concerned & 22 & 23 & 13 \\
\hline Neither concerned nor unconcerned & 3 & 3 & 1 \\
\hline Mainly unconcerned & 6 & 4 & 3 \\
\hline Totally unconcerned & 3 & 2 & 1 \\
\hline Don't know & 3 & 2 & 1 \\
\hline & $100 \%$ & $\mathbf{1 0 0 \%}$ & $100 \%$ \\
\hline
\end{tabular}


Table 4: Concern posed by transport of nuclear material

\begin{tabular}{|c|c|c|c|}
\hline & $\begin{array}{c}\text { Traditionalists } \\
\%\end{array}$ & $\begin{array}{c}\text { Mixed type } \\
\%\end{array}$ & $\begin{array}{c}\text { Individualists } \\
\%\end{array}$ \\
\hline Very concerned & 54 & 60 & 69 \\
\hline A little concerned & 25 & 26 & 21 \\
\hline Neither concerned nor unconcerned & 5 & 5 & 3 \\
\hline Mainly unconcemed & 9 & 7 & 4 \\
\hline Totally unconcemed & 5 & 3 & 2 \\
\hline Don't know & 3 & 2 & $\mathbf{l}$ \\
\hline & $100 \%$ & $100 \%$ & $100 \%$ \\
\hline
\end{tabular}

Columns may not total 100 because of rounding.

Source: RAS national poll for Newcastle University, February $1997 ; n=3105$.

The above tables show that the absolute level of expressed concern is fairly high for all groups, but rises consistently from the traditionalist group to the individualists. The responses of the former group evince a systematically lower level of concern about risks posed by nuclear power plants than individualists. Individualists are more risk aware than traditionalists.

We now turn to the relationship between risk awareness and risk aversion. The following table shows the correlations between beliefs about risks associated with aspects of the nuclear industry and overall attitudes towards it.

Table 5: Correlations between level of concem about risks associated with aspects of the nuclear industry and overall favourability towards it

\begin{tabular}{|l|c|c|}
\hline & Traditionalists & Individualists \\
\hline Nuclear power plants & & -.45 \\
\hline Nuclear waste disposal & -.52 & -.23 \\
\hline Transport of nuclear material & -.42 & -.30 \\
\hline
\end{tabular}

Source: RAS national poll for Newcastle University, February 1997; n=3105.

We found a negative correlation between the risk connotations and the overall evaluation of the nuclear industry. This not perhaps surprising. People who believe that there are grounds for risk-related concern about an industry, are unlikely to evaluate it favourably, other things being equal. In other words, a high level of risk concern will be translated into a low level of favourability towards the industry. This relationship is revealed as a negative correlation in our data (i.e. high risk concern is associated with low approval for the attitude object). The key finding is that the data show differences between individualists and traditionalists in this regard. Among individualists, the strength of the correlation between the risk connotations of the industry and the respondent's overall attitude towards the nuclear industry is consistently weaker than for members of the "traditional" group.

\section{CONCLUSION}

Contemporary society in Britain is characterised by increased individualism. We find that there is a paradox of risk perception among individualists. They are more risk aware but less risk averse. The lower correlation between the risk connotations and attitudes towards the nuclear industry among individualists points, we believe, towards the heightened importance of the self in their evaluation process as they undertake "balancing behaviour", a cognitive cost-benefit analysis based upon a referent's perceived benefits and disbenefits. The extent to which a particular risk, even a dread risk like radiation, is 
perceived as salient in the formation of an attitude is related to the degree to which they believe it will be likely to affect them personally. Individualists may be more sophisticated in their evaluation processes in general and in their use of risk in that process in particular.

This finding has significant implications for effective risk communication. Risk communicators need to frame their communications in a way consistent with the interests of their intended audiences. Even if something is perceived as highly risky, other beliefs about that referent may be taken into account through sophisticated cost benefit calculations in the formation of an attitude. However, in this age of individualisation, the key question underlying this process may be quite a simple one - What's in it for me?

\section{Reference}

[1] Beck, Ulrich (1992) Risk Society (Sage, London)

[2] Piller, Charles (1991) "The Fail Safe Society" Berkley, University of California Press, p. 19.

[3] Slovic, Paul (1987) "Perception of Risk." Science, 236, p.285

[4] Wylie, Rick and Hague RAH (2000). Risk and Values in Contemporary Britain. Newcastle: Newcastle University

[5] Giddens, Anthony (1991) Modernity and Self-Identity (Polity, Cambridge), p. 28

[6] Beck, Ulrich (1996). "Risk Society and the Provident State", Risk, environment and Madernity, Towards a New Ecology, edited by Lash, Scott, Szerszynski, Bronislaw and Wynne, Brian (Sage, London), p. 34

[7] Beck, Ulrich (1992). "From Industrial Society to Risk Society: Questions of Survival, Social Structure and Ecological Enlightenment", Cultural Theory and Cultural Change, edited by Featherstone, Mike (Sage, London)

[8] Wildavsky, Aaron (1988) Searching for Safety. (Transaction Books, New Brunswick)

[9] Adams, John (1995) Risk (UCL Press, London)

[10] Gaskell, Deborah (1997) "Risk and Reason", Chemistry in Britain, July 1997, p. 37 